\title{
Everything to everyone? Not when you are internally divided
}

\author{
Roni Lehrer \\ University of Mannheim, Germany
}

Nick Lin

Academia Sinica, Taiwan

\begin{abstract}
Despite the normative importance of a clear party stance to political competition and representation, research has discovered that parties and candidates tend to employ the "broad-appeal" strategy to becloud their true policy intentions in order to expand their electoral support. Empirical work by Somer-Topcu demonstrates evidence that being ambiguous indeed helps political parties gain votes in elections since equivocal messages make voters underestimate the preference divergence between themselves and parties. In this article, we ask under what conditions would the "broad-appeal" strategy fail to work? We then propose internal unity of political parties as a critical condition for this strategy to work effectively. If a party is internally divided, conflict within the party accentuates the true policy intentions of the party and then counterbalances the discounting effect of being ambiguous on voters' perceptions. Using survey data from the German Internet Panel, we show that voters underestimate policy distances to ambiguous parties only if they perceive them as internally united. Using a two-stage estimator, we also present evidence that the underestimation of policy distances affects voters' vote choices.
\end{abstract}

\section{Keywords}

intraparty politics, perceived policy distance, policy ambiguity, spatial model, vote choice

\section{Motivation}

When deciding on their policy messages, there is a list of good reasons for political parties to posit themselves in a "fog of ambiguity" (Downs, 1957: 136) - that is, to embrace an ambiguous policy platform (Alesina and Cukierman, 1990; Argones and Neeman, 2000; Bräuninger and Giger, 2018; Glazer, 1990; Meirowitz, 2005; Rovny, 2012; Shepsle, 1972). In her recent work, Somer-Topcu (2015) demonstrates that this "broad-appeal" strategy makes voters underestimate the ideological distance between themselves and political parties. In this article, we explore the limits of this broad-appeal strategy and argue that we need to distinguish between parties that deliberately hide their policy intentions without internally fighting and those that internally fight over policies and are, thus, perceived as ambiguous. We maintain that the broad-appeal strategy loses its effectiveness when voters perceive a party as internally fighting. This is because internal conflict accentuates the true intentions of different party messages, and therefore voters can better locate the party and estimate the policy distance between themselves and the party (Hersh and Shaffner, 2013, see also Greene and Haber, 2015).

Anecdotal evidence from two German parties illustrates our argument. Björn Höcke, a well-known state-level parliamentarian of the right-populist party Alternative für Deutschland (AfD), gave a speech challenging the consensus in German society that perceives the Holocaust as central to German post-WWII identity. While the moderate faction within the party tried to suspend Höcke from the party for taking right-wing extremist positions, the

Paper submitted 27 March 2018; accepted for publication II October 2018

Corresponding author:

Roni Lehrer, Collaborative Research Center 884, University of Mannheim, B6, 30-32, 68I31, Mannheim, Germany.

Email: lehrer@uni-mannheim.de 
nationalist party faction blocked the suspension procedures in a party board vote. The media covered this internal fight broadly, including reports on both coparty chairpersons taking opposing sides (Kamann, 2017). ${ }^{1}$ The month following these internal fights, AfD's support among voters declined by 3 percentage points, that is, by one quarter. ${ }^{2}$ We attribute this to both nationalist and moderate AfD supporters being afraid of the possibility that the party could choose the "wrong" way.

At the same time, the German Social Democrats' (SPD) chairman announced that former European Parliament (EP) President Martin Schulz would take over as SPD chairman and run for Chancellor against Angela Merkel in the 2017 general election. All SPD party factions immediately embraced this decision, and Schulz was elected as party leader unanimously - which had never happened in more than 150 years of the SPD history. Schulz had enjoyed an excellent reputation in Germany as EP President; however, his stances on domestic politics and especially whether he would seek to bring change to SPD policy positions were virtually unknown (Börnsen, 2017; Hickmann, 2017). Moreover, this policy uncertainty received a significant share of media attention. Nevertheless, in the following month, polls revealed an increase of SPD vote intentions by about $50 \%$, virtually drawing level with Angela Merkel's Christian Democrats (Caspari, 2017). Even though potential SPD and AfD voters were similarly clueless about their parties' future policy positions, SPD support increased rapidly, whereas AfD support declined. We believe that the fact that SPD factions did not present opposing policy proposals publicly, while AfD factions did, played a major role in attracting and turning away voters, respectively.

Based on this background, we argue that voters underestimate their policy distance to a party that embraces an ambiguous policy platform, yet this only occurs when the party is not perceived as internally fighting. This is because perceived intraparty conflict improves voters' estimation of the policy distance between themselves and the party. Most importantly, we contend that voters further adjust their voting behavior after updating their beliefs of policy distance to the party with observed intraparty conflict. We then empirically test our theory using survey data from the German Internet Panel (GIP; Blom et al., 2015). Our analyses reveal strong support for the above argument. Specifically, we first show evidence that voters underestimate the ideological distance between themselves and the party with ambiguous policy position only when the party is perceived as internally coherent. We then use a two-stage estimator (Bergholt and Lujala, 2012) and present evidence that intraparty coherence is a necessary condition for the positive relationship between policy ambiguity and electoral performance (Greene and Haber, 2015).

This study has important implications for several research endeavors. The implications for parties' electoral strategies are that besides choosing a policy position
(Budge, 1994; Downs, 1957; Kedar, 2005; Laver, 2005; Somer-Topcu, 2009; Wittman, 1973) and its level of ambiguity (Alesina and Cukierman, 1990; Argones and Neeman, 2000; Bräuninger and Giger, 2016; Glazer, 1990; Shepsle, 1972), controlling party representatives to deliver messages without being suggestive of intraparty fights is a central challenge for party leaders. This, in turn, suggests a new perspective on the debate on the value of intraparty democracy (Teorell, 1999). Moreover, our results sketch a route for future research to further scrutinize why intraparty unity is a precious resource that parties seek particularly before elections (Greene and Haber, 2015). In terms of political representation, while the Responsible Party Model (Mair, 2008) assumes that clear policy positions can link parties to citizens, our findings challenge this relationship and suggest that it only exists if voters perceive intraparty conflict. Finally, this study also adds crucial evidence to the debate on whether policy ambiguity pays off (Aldrich et al., 2018; Somer-Topcu, 2015; Tomz and Van Houweling, 2009) by suggesting that party unity functions as a conditioning factor. We discuss these contributions in more detail in the final section of this article. We now turn to our theoretical expectations and their empirical tests.

\section{Theory}

Electoral competition requires political parties to take positions in the policy space in order to respond to voters' policy preferences (Downs, 1957). Strategies of position taking may include proposing a very concrete policy platform or being vague about what the party actually stands for. Prior theoretical work contends that being ambiguous in elections is a superior strategy as it helps parties gain electoral support when future political environments are uncertain, particularly when politicians are unsure about voters' policy preferences (e.g. Alesina and Cukierman, 1990; Argones and Neeeman, 2000; Argones and Postlewaite, 2002; Callander and Wilson, 2008; Glazer, 1990; Jensen, 2009; Shepsle, 1972). Empirical and experimental evidence further reveals that presenting an ambiguous policy platform is indeed electorally beneficial for political parties (SomerTopcu, 2015; Tomz and Van Houwelling, 2009), even though some voters dislike vague policies (Bartels, 1986; Enelow and Hinnich, 1981; Gill, 2005).

In her recent study using cross-country surveys, SomerTopcu (2015) is able to (partially) trace the causal mechanism that makes voters more likely to vote for an ambiguous party. She demonstrates that parties with an ambiguous platform tend to perform better in elections since the strategy significantly makes voters underestimate the actual ideological distance between their own policy preferences and the policy position of the ambiguous party. By sending out mudded policy signals, political parties may appeal to different electorates with diverse policy interests and convince these voters that they are ideologically close to them. 
In this way, holding an ambiguous policy position seems to be a great winning strategy, at least in the short run, for political parties that aim to expand their electoral base.

However, the broad-appeal strategy can fail under certain circumstances (Somer-Topcu, 2015: 844). We argue that an ambiguous policy position can evolve in two ways and contend that the way in which it evolves determines whether the strategy works or not. On the one hand, a party can deliberately decide to send ambiguous policy signals, for instance, by avoiding to take a clear stance at all, or by highlighting different parts of its manifesto to different subconstituencies without directly contradicting other party messages or even downplaying internal policy differences intentionally. This strategy may result in an ambiguous policy position without intraparty fights. Martin Schulz's early 2017 election campaign is a good example of this pattern. In the first weeks under Schulz's leadership, SPD policy was vague, and at the same time, there were no internal fights. Voters (unknowingly) felt attracted by this combination, and SPD vote shares in polls increased significantly at the time.

On the other hand, a party can have an ambiguous policy position because the party is internally fighting. When party factions propose distinct policy proposals and publicly criticize and fight against each other, the party platform is also very likely to be perceived as ambiguous since voters are confused about what exactly the party stands for. Yet, voters clearly observe the conflict within the party and receive clear-cut policy messages from party factions. The debate on Höcke's speech in early 2017 is an example of this second, conflictual type of party policy ambiguity. There were severe fights within the party, which made voters puzzled about future party policy, and further led to a significant drop in AfD support.

We argue that whether a party is perceived as internally fighting or not is relevant to whether voters realize that the policy messages they like about an ambiguous party are foiled by the party's second face. When the party is cohesive, policy differences are not highlighted and voters are likely to underestimate the policy distance between themselves and the party. When the party is internally fighting, however, voters are made aware of policy differences within the party and, therefore, do not misunderstand the party's true policy intentions. This also suggests that the extent to which a party is ambiguous is not endogenous to intraparty conflict. In fact, the survey data we use below indicate that the correlation between these two variables is only about 0.14 .

Our argument can also be visualized through a simple exercise of simulation. Consider a party with a unified party leadership that is perfectly capable of controlling the content of policy messages its agents send to voters. This party is able to set up a level of policy ambiguity by having its agents send a set of varying policy messages. Imagining that every policy message can be placed on an 11-point left-right scale, the left panel of Figure 1 shows the distribution of messages that can evolve if this party expresses an ambiguous policy position in 1000 policy messages. A voter of this party should have difficulty to detect that some of the party messages are not particularly desirable to her. For instance, a voter whose policy preference locates at point 3 on the scale may not realize that the message designed for voters whose ideal point locates at 7 is so far away from her ideal position as the party is coherently hiding its policy intention and all party agents are deliberately downplaying differences between party messages.

Now, consider another party with a divided party leadership controlled by two party leaders. Each party leader requests her agents to send messages that are intended to promote their own policy interests within the party. We depict this party in the right panel of Figure 1. The party is internally divided between a light gray and a dark gray faction and each of them sends 500 policy messages. Note that in these cases, we designed the two arising distributions with identical ambiguity scores at $0.47 .{ }^{3}$ While these two distributions are remarkably similar, voters of the divided party clearly can observe the internal split and different messages originated from the intraparty policy disagreement if party agents are publicly fighting over policies and are not downplaying or hiding internal differences. This is because public fights reveal conflicting and potentially contradictory aspects to a broad public that otherwise only some voters would realize. Therefore, the same voter at position 3 on the scale can easily observe those messages that were designed for voters located at the righthand side of the spectrum (i.e. the light gray faction). Likewise, a voter at position 7 can also observe the messages created by the dark gray fraction. In this case, we suggest that voters are more likely to comprehend the opposing content of party messages, and hence they are less likely to believe that the party is close to them, which implies that they are less likely to support this party. ${ }^{4}$

A similar link to the one we suggest between policy conflict and voters' awareness of party positions is also evident in the recent literature on policymaking in coalition governments. Specifically, since multiparty governance blurs the policy profiles of coalition parties, voters may have a hard time to tell coalition parties apart (Fortunato and Stevenson, 2013; Martin and Vanberg, 2011). Hence, parties in coalitions tend to express their true policy intentions through different tools such as floor speeches and press releases (Sagarzazu and Klüver, 2017; Martin and Vanberg, 2008), particularly when policy disagreement exists. Policy information embedded in these activities, along with conflict, further helps voters pin down the true policy position of coalition parties (Spoon and Klüver, 2017). The similarity to intraparty conflict is immediate. Just as coalition conflict accentuates the difference of policy preferences between coalition parties and consequently informs voters where these parties locate in the ideological 


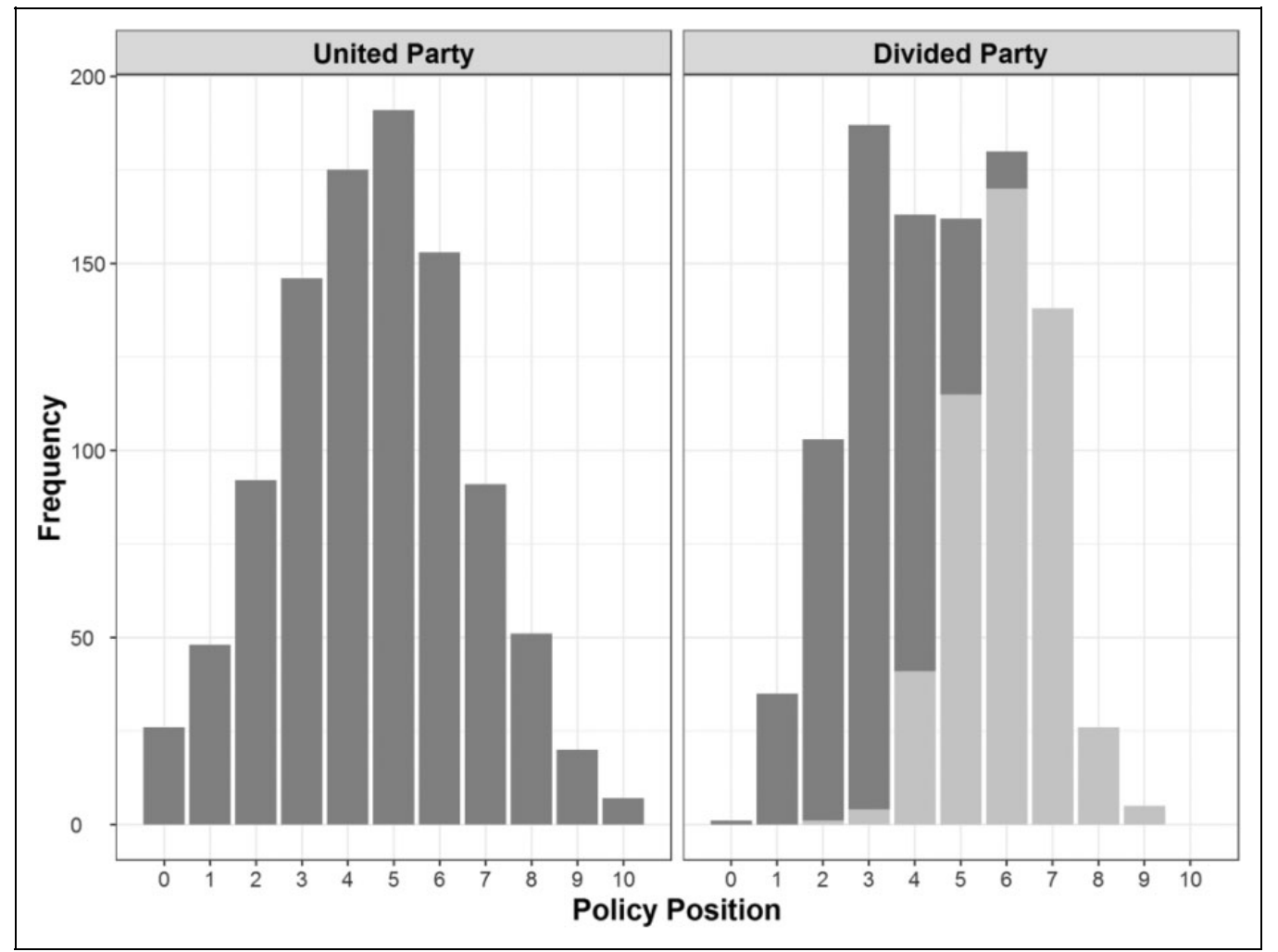

Figure I. Two distributions of 1000 party messages with identical agreement scores.

landscape, conflict within a party highlights the policy intentions of party factions and helps voters place the party accordingly. ${ }^{5}$

To reiterate, we argue that the broad-appeal strategy (i.e. being ambiguous) does not make voters underestimate the ideological divergence between a party and their own policy interests when the party is perceived to be internally divided. This is because intraparty conflict reveals the purpose of different party policy messages (as well as the party's true position) and therefore offsets a voter's miscalculation of the true ideological distance between the party and his or her ideal position. On the contrary, if the party is being unequivocal about its policy goals, its true policy intention and policy position can be observed easily by the electorate. In this case, party unity should impose no effect on voters' perceptions of the distance between their own interests and the party's position. Our hypotheses can be formulated as:

Ambiguous party hypothesis: When a party is ambiguous in its policy platform, a voter's perception of the distance between the party and herself decreases as the voter's perceived unity of the party increases.

Unambiguous party hypothesis: When a party is unambiguous in its policy platform, a voter's perceived unity of the party has no effect on her perception of the distance between the party and herself.

\section{Data and modeling strategy}

To examine our argument, we require information on how voters place themselves and political parties on an ideological spectrum, and most importantly, their perception of the extent to which a party is united or divided. We rely on surveys conducted by the GIP (Blom et al., 2015), which is a panel survey study based on a random sample of the German population. Germany is an interesting country to test our hypotheses because it provides variation in both party policy ambiguity and party unity. At the same time, German parties are fairly cohesive (e.g. in their parliamentary behavior) which makes Germany a hard case to test our hypotheses because voters have fewer clues to judge parties' internal unity. Thus, if our hypotheses find support in Germany, they are likely to find support in other countries as well. ${ }^{6}$

In particular, we use data of four GIP waves from autumn 2012 to 2013, respectively (Blom et al., 2016a, 2016b, $2016 \mathrm{c}, 2016 \mathrm{~d}) .^{7}$ In the surveys, respondents were asked to place the five major German parties and themselves on an 11-point left-right continuum. Also, respondents were asked to rate party unity using an 11-point scale. These are the major questions that we will use to generate our dependent variable and the independent variables of interest. 
Similar to Somer-Topcu (2015), our dependent variable is the perceived distance between a respondent $i$ and a party $k$. It is measured as the absolute distance between respondent $i$ 's self-placement and her placement of party $k$. As a result, each respondent $i$ can enter the data $k$ times for each wave she answered and the unit of analysis is, therefore, the respondent-party-wave. Also, as we will discuss below, our data include several variables at both the respondent and the party levels.

Our theory concerns the interaction between actual distance, party ambiguity, and perceived party unity. To measure the actual ideological distance between respondent $i$ and party $k$, we need information on the true policy position of political parties. Unlike Comparative Study of Electoral Systems (CSES) surveys, the GIP survey does not include expert evaluation of party positions. We, therefore, follow Spoon and Klüver's (2017) strategy by using the averaged perception of all respondents as a proxy of actual party positions. ${ }^{8}$ Thus, actual distance captures the distance between each respondent $i$ 's self-placement and the mean of all respondents' placements of party $k$.

To measure party ambiguity, we follow Somer-Topcu (2015) by utilizing the perceptual agreement score developed by Van der Eijk (2001). We convert the variable so that greater numbers indicate a lower consensus among voters about a party's ideological location. ${ }^{9}$ That is, greater numbers show a higher level of party ambiguity. Since we will be dealing with a three-way interaction term, for simplicity, we create an indicator variable to capture the parties that attempt to appeal broadly. Parties with values greater than the mean value of the ambiguity score are assigned the value 1 as ambiguous party, and 0 otherwise. ${ }^{10}$

Finally, to capture perceived party unity, we use the GIP question that asks respondents to indicate their perception of a party's cohesiveness using an 11-point scale. ${ }^{11}$ This variable essentially measures respondent $i$ 's perceived intraparty coherence of party $k$.

Econometrically, our model can be formulated as the following:

$$
\begin{aligned}
& \text { Perceived Distance } \left._{i, k}\right]=\beta_{1} \times\left[\text { Actual } \text { Distance }_{i, k}\right] \\
& +\beta_{2} \times\left[\text { Ambiguous Party }_{,, k}\right] \\
& +\beta_{3} \times\left[\text { Perceived Unity }_{,, k}\right] \\
& +\beta_{4} \times\left[\text { Ambiguous Party }_{i, k} \times \text { Actual Distance }_{i, k}\right] \\
& +\beta_{5} \times\left[\text { Ambiguous Party }_{i, k} \times \text { Perceived Unity }_{i, k}\right] \\
& +\beta_{6} \times\left[\text { Actual Distance }_{i, k} \times \text { Perceived Unity }_{i, k}\right] \\
& +\beta_{7} \times\left[\text { Actual Distance }_{i, k} \times \text { Perceived Unity }_{i, k}\right. \\
& \left.\quad \times \text { Ambiguous Party }_{i, k}\right] \\
& +\beta_{8} \times \text { Controls }_{i, k} \\
& +\beta_{0} \times \text { Intercepts }
\end{aligned}
$$

Since we intend to test whether party unity is an important mediator that conditions the effect of the broad-
Table I. Descriptive statistics.

\begin{tabular}{lcccc}
\hline Variable & Mean & $\begin{array}{c}\text { Standard } \\
\text { deviation }\end{array}$ & Minimum & Maximum \\
\hline Perceived distance & 2.444 & 2.095 & 0 & 10 \\
Actual distance & 2.168 & 1.614 & 0.078 & 9.088 \\
Ambiguous party & 0.617 & 0.486 & 0 & 1 \\
Perceived unity & 5.498 & 2.409 & 1 & $1 \mathrm{I}$ \\
Party supporter & 0.123 & 0.329 & 0 & 1 \\
Education & 4.615 & 1.232 & 1 & 6 \\
Single issue party & 0.18 & 0.384 & 0 & 1 \\
In government & 0.407 & 0.491 & 0 & 1 \\
Vote share & 19.217 & 8.741 & 10.7 & 33.8 \\
Second wave & 0.488 & 0.500 & 0 & 1 \\
\hline
\end{tabular}

appeal strategy suggested by Somer-Topcu (2015), we follow her modeling strategy by including the same set of control variables in our model. Specifically, we add a vector of covariates that have been linked to respondents' political knowledge on parties' ideological positions (e.g. Dahlberg, 2009; Somer-Topcu, 2015). At the individual level, we first include a dummy variable that indicates whether respondent $i$ 's party identification is affiliated with party $k$. Supporters of a party, according to the projection literature, tend to assimilate the party's ideological location to their own position (e.g. Merrill et al., 2001). Therefore, we expect party supporters to shorten the perceived distance between themselves and the party they support. Another individual level variable considers the respondents' education level as it should be positively correlated with respondents' ability to map parties on the policy space.

At the party level, we include a dummy variable that indicates whether a party is a single issue party. ${ }^{12}$ This is because single issue parties engage in fewer issues than the so-called "catch-all" parties and, most importantly, they rarely compete on the traditional left-right dimension. Consequently, voters may know less about the ideological profile of these single issue parties. In addition, we also control for a dummy variable that indicates government membership $^{13}$ and a variable that captures party vote shares at the most recent general election. Government parties and parties with a large share of seats are likely to receive greater media attention, which makes voters better informed about their policy positions. Finally, considering the nature of the data structure - an observation for each combination of respondents, parties, and waves - we estimate a multilevel model with random intercepts at the party and the partywave level, as well as time fixed effects. ${ }^{14}$ Descriptive statistics are reported in Table 1.

\section{Empirical results}

Table 2 shows the results of our statistical analysis. ${ }^{15}$ In Model 1, we first perform a simple model with the variables of our interest, and in Model 2, we estimate a full model 
Table 2. The effect of party ambiguity and unity on voters' perceived distance to the party.

\begin{tabular}{|c|c|c|c|c|}
\hline \multirow[b]{2}{*}{ Actual distance } & \multicolumn{2}{|c|}{ Model I } & \multicolumn{2}{|c|}{ Model 2} \\
\hline & $0.969 * *$ & $(0.039)$ & $0.962 * *$ & $(0.039)$ \\
\hline Ambiguous party & $0.655^{* *}$ & $(0.174)$ & $0.506 * *$ & $(0.180)$ \\
\hline $\begin{array}{l}\text { Distance } \times \text { Ambiguous } \\
\text { Party }\end{array}$ & -0.060 & $(0.056)$ & -0.050 & $(0.056)$ \\
\hline Perceived party unity & -0.007 & $(0.022)$ & 0.013 & $(0.022)$ \\
\hline Distance $\times$ Unity & -0.006 & $(0.006)$ & -0.010 & $(0.006)$ \\
\hline Ambiguous Party $\times$ Unity & $-0.062 *$ & $(0.028)$ & $-0.047^{\dagger}$ & $(0.028)$ \\
\hline $\begin{array}{l}\text { Distance } \times \text { Ambiguous } \\
\text { Party Unity }\end{array}$ & -0.010 & $(0.009)$ & -0.012 & $(0.009)$ \\
\hline Partisan supporter & & & $-0.716 * *$ & $(0.058)$ \\
\hline Education & & & 0.021 & $(0.015)$ \\
\hline Single issue party & & & 0.104 & $(0.07 I)$ \\
\hline Government party & & & $0.126 *$ & $(0.059)$ \\
\hline Vote share & & & -0.000 & $(0.003)$ \\
\hline Second wave & & & $-0.096^{\dagger}$ & $(0.048)$ \\
\hline Constant & $0.379 * *$ & $(0.14 I)$ & $0.343^{*}$ & $(0.163)$ \\
\hline Random effect-Party & $-2.840 * *$ & $(0.610)$ & $-|9.23|^{\dagger}$ & $(8.805)$ \\
\hline $\begin{array}{l}\text { Random effect-Party } \\
\text { wave }\end{array}$ & $-3.445^{*}$ & $(1.396)$ & $-20.20 I^{* *}$ & $(6.183)$ \\
\hline $\begin{array}{l}\text { Random effect- } \\
\text { Residual }\end{array}$ & $0.405^{* *}$ & $(0.009)$ & $0.393 * *$ & $(0.009)$ \\
\hline Observations & 686 & & 6867 & \\
\hline Log likelihood & -125 & 528 & -124 & \\
\hline
\end{tabular}

Note: Standard errors are in parentheses.

${ }^{* *} p<0.01 ;{ }^{*} p<0.05 ;{ }^{\dagger} p<0.1$.

including all control variables. A first glance suggests that the results are fairly robust across models, although interpreting the three-way interaction effects is difficult by simply reading the coefficients. To better understand the meaning of the estimated results and examine our hypotheses properly, we follow the strategy suggested by King et al. (2000) to simulate and plot the predicted values of the dependent variable (i.e. perceived distance) using the estimated parameters of the variables of interest in Model 2. The predicted values of perceived distance are calculated by setting whether a party is being an ambiguous party, allowing perceived unity to range from its minimum to maximum values, and holding other control variables at their mean values. In the left panel of Figure 2, we present the situation where a party has a concrete policy stance, while in the right panel, we show the case where a party employs the broadappeal strategy. The white lines in the figure indicate the point estimates of the predicted values while the gray areas show the corresponding $95 \%$ confidence intervals.

As one may immediately observe from the right panel, when the party is equivocal about its policy platform, the discounting effect of this "broad-appeal" strategy on a voter's perceived distance between the party and herself declines significantly as the voter's perception of the party's unity decreases. Respondents tend to believe that an ambiguous party is ideologically closer to them when the party is perceived to have a higher level of cohesiveness, ceteris paribus. In line with our expectation, perceived intraparty conflict exposes the actual ideological divergence between the party and the voters. On the contrary, in the left panel where the party takes an unequivocal stance, the story apparently works differently. When the party has a concrete plan for its future policies, it helps voters learn its true policy intentions and where it stands in the policy space. As a result, our respondents have a very clear idea of the actual distance between themselves and the party, regardless of whether they perceive the party as internally divided or not.

Comparing the two graphs in Figure 2 also reveals a very interesting finding. When a party is perceived to be coherent, the broad-appeal strategy works perfectly as Somer-Topcu (2015) suggests. Respondents tend to perceive the party ideologically closer to their own positions when the party is ambiguous rather than concrete. For instance, when the party's unity is perceived to be at 9 on the 11-point scale, a hypothetical voter perceives a policy distance of 2.15 units between herself and the party when the party embraces an ambiguous platform but sees a distance of 2.42 units when the party communicates a clear policy program. This difference is statistically significant. On the contrary, when the party is perceived to be internally divided, playing the broad-appeal strategy significantly turns voters further away than keeping a crystal clear policy platform does. When the party's unity is perceived to be at 2 , the hypothetical voter would observe a distance of 2.73 units if the party is equivocal, but only perceives a distance of 2.48 units when the party is unambiguous. These findings together suggest that, when the intraparty conflict exists, a party may choose to stay clear rather than jumping into a "fog of ambiguity" as the latter clearly alienates potential voters. Overall, we take the above findings as supportive evidence to our theoretical hypotheses.

\section{The electoral consequence of ambiguity while being internally divided}

Up until now, we have demonstrated that the effect of the "broad-appeal strategy" on voters' perceived distance between their own position and the perceived party position is largely conditional on the extent to which a party is perceived to be internally coherent. To recap, we find that being ambiguous helps parties influence voter perceptions in a favorable way (i.e. reduce the perceived distance) only when the party is perceived to be internally unified and that this effect declines as the perceived intraparty conflict escalates. Our results imply that there should be an electoral consequence of the interplay between party ambiguity and party unity because (perceived) policy distance affects vote choices (Downs, 1957). Voters should be more likely to vote for a party when they feel close to it, that is, when the party is equivocal about its policy platform and not internally fighting, and less likely to do so when the party 


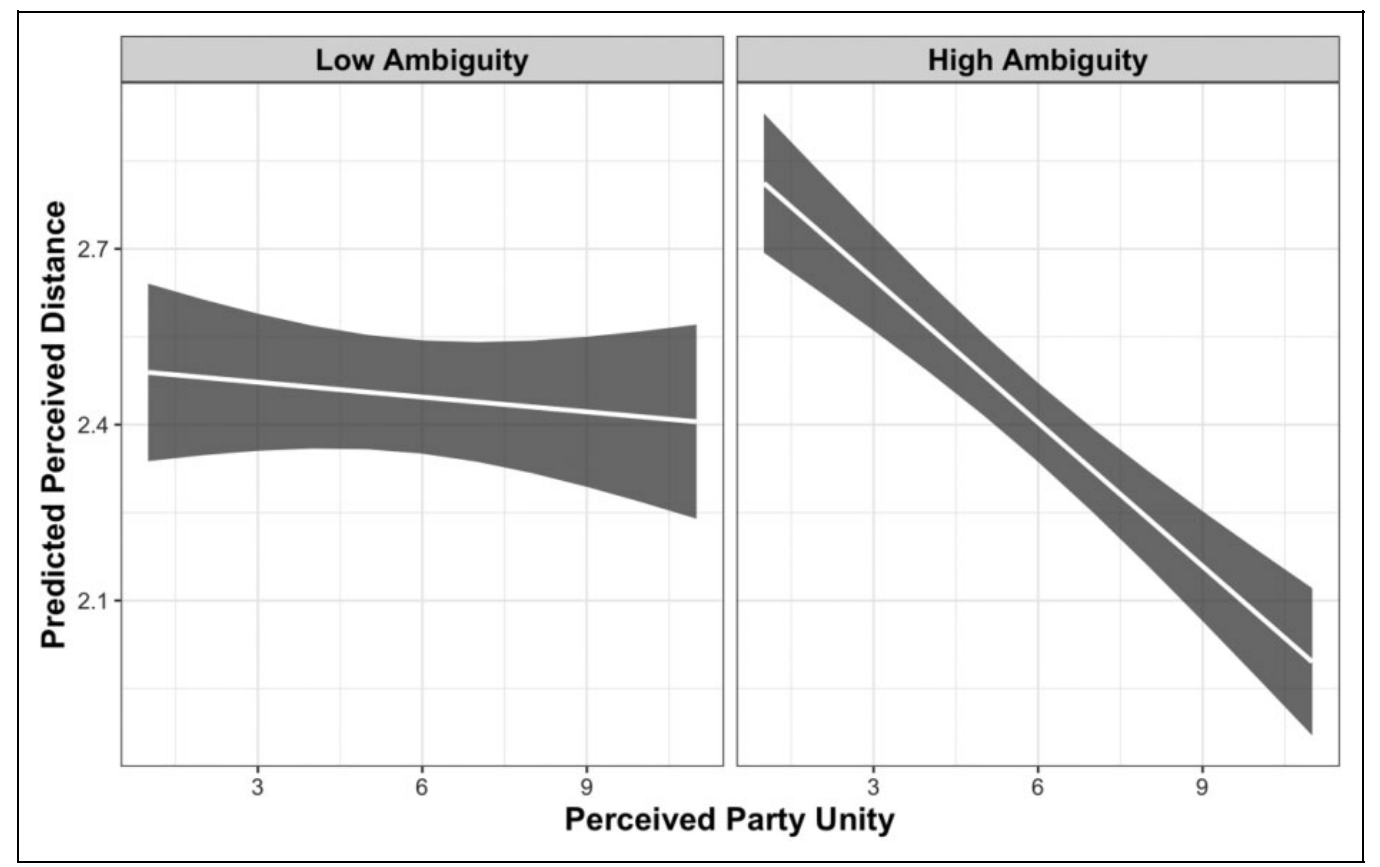

Figure 2. The interaction effect of perceived unity and ambiguity on perceived distance.

Note: The white lines in the plot show the point estimates, and the gray areas indicate the $95 \%$ confidence intervals.

remains ambiguous yet its leaders fight publicly over future policies. In this section, we provide an empirical test to examine the above expectations.

To empirically explore how the electoral consequence of the broad-appeal strategy is mediated by party unity, one approach is to add an objective measure of party unity and its interaction term with party ambiguity in the same partylevel model that Somer-Topcu (2015) performs in her research. Unfortunately, this strategy is not feasible at the moment as such a data set of party unity is not available. As an alternative, we utilize our GIP survey to model respondents' voting behavior and investigate how their vote choices are influenced by whether a party is ambiguous and whether the party is perceived to be unified.

Note that our argument suggests that the effects of party ambiguity and party unity on voting behavior are indirect. These variables first affect one's perception of the distance between oneself and a focal party, as we have demonstrated, and then the updated perceived distance determines whether one would vote for the party or not. As a result, we do not perform a model that simply regress respondents' choices against actual distance, party ambiguity, and party unity (as well as their interaction terms). Rather, we explore the electoral implications using a two-stage model (Bergholt and Lujala, 2012). In the first stage, we conduct a full model of respondents' perceived distance (i.e. Model 2 in Table 2 ) in order to obtain the predicted perceived distance for each respondent $i$ and party $k$. We then use this predicted distance as the major explanatory variable in a second-stage model where the dependent variable is the respondent's vote
Table 3. The effect of party ambiguity and unity on voting behavior.

\begin{tabular}{|c|c|c|c|}
\hline \multirow[b]{2}{*}{$\begin{array}{l}\text { Predicted perceived } \\
\text { Distance }\end{array}$} & Model 3 & \multicolumn{2}{|c|}{ Model 4} \\
\hline & $-0.966 * * \quad(0.059)$ & $-0.478 * *$ & $(0.056)$ \\
\hline Partisan voter & & $1.786 * *$ & $(0.14 I)$ \\
\hline Single issue party & & 0.042 & $(0.189)$ \\
\hline Government party & & $-0.478 * *$ & $(0.115)$ \\
\hline Vote share & & $0.044 * *$ & $(0.006)$ \\
\hline Choices & 762 & 762 & \\
\hline Log likelihood & -1243.4 & -100 & \\
\hline
\end{tabular}

Note: Bootstrapped standard errors are in parentheses. $*_{*} p<0.01$; $*_{p}<0.05 ;{ }^{\dagger} p<0.1$.

choice from a set of parties. ${ }^{16}$ We use a conditional logit model (McFadden, 1973) in the second stage to estimate the impacts of perceived distance on respondents' vote choice. We then bootstrap this two-stage model 1000 times to account for first-stage prediction uncertainty that feeds into the second stage. Results are presented in Table 3.

Consistent with our expectation and the existing spatial voting literature, voters' perceptions of a party significantly influence their willingness to vote for the party. As one may observe, this finding is robust after taking into account other covariates, including a strong predictor of vote choice: party identification. Clearly, when the perceived distance between a respondent $i$ and a focal party $k$ increases, the probability for the respondent to vote for the party decreases. Yet, this is not exactly our 


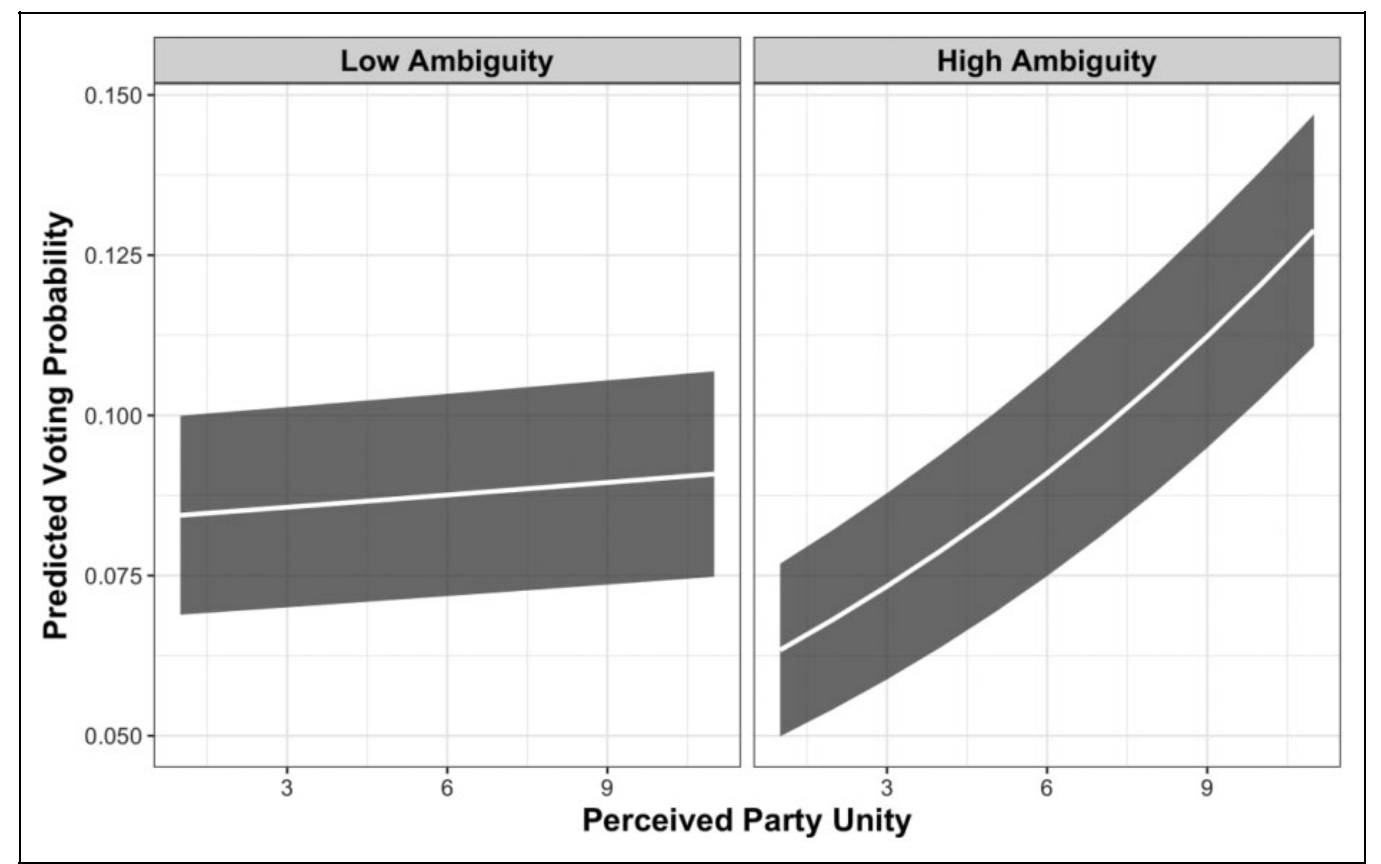

Figure 3. The interaction of perceived unity and ambiguity on voting behavior.

Note: The white lines in the plot show the point estimates, and the gray areas indicate the $95 \%$ confidence intervals.

interest here as we are more concerned with how party ambiguity and perceived party unity shape one's vote choice. Ideally, we would want to generate and plot predicted voting probabilities that are derived based on the predicted values of perceived distance that varies at different levels of party unity and whether a party is being ambiguous. Since we have already produced a set of the values of predicted perceived distance (and plotted them in Figure 2), now we simply take these values and employ the estimated parameters from Model 3 to calculate the predicted voting probabilities of vote choice. The final results are visually illustrated in Figure 3.

Corresponding to Figure 2 above, in the right panel of Figure 3, we plot the predicted voting probability based on the predicted perceived distance in the scenario where a party is advertising an ambiguous platform. In line with our expectation, as greater values of perceived unity shorten the perceived distance between voters and the party, it simultaneously enhances the party's profile and makes voters more likely to vote for the party. In the left panel of Figure 3, we plot the predicted voting probability in the case where the party embraces a clear policy program. Consistent with our expectation, the likelihood of voters to vote for an unequivocal party is not affected by perceived party unity. Also, comparing across panels, we see that when the perceived party unity is high, the broadappeal strategy is more electorally beneficial than making concrete policy plans. In fact, the probability of voting for an internally united party increases by almost $50 \%$ when a party is ambiguously about its policies than when it embraces a clear stance. This, again, confirms our theoretical conjecture.

\section{Conclusion}

From a normative perspective, political parties in multiparty systems should pursue the "product differentiation" strategy by taking an unequivocal policy stance in order to distinguish themselves from their competitors (APSA, 1950; Mair, 2008). Different from this normative perspective, a recent work by Somer-Topcu (2015) presents strong evidence that "broad-appeal" seems to be a better winning strategy, at least in the short term, because it helps parties hide their true policy intentions, target a wide range of voters with different preferences, and convince voters that the party is ideologically close to them. Most importantly, parties playing the ambiguous card indeed perform better in elections than their competitors who embrace the product-differentiation strategy (i.e. taking a concrete policy stance).

We add to these considerations the argument that intraparty cohesiveness is a necessary precondition for the broadappeal strategy to work because internal fights make voters realize that different policy positions within the party exist. As a result, they are not led astray by vague policy messages. We present empirical results that corroborate this argument. When a party plays the broad-appeal strategy, the discounting effect of ambiguity on one's perceived distance between self-placement and party location works exactly as SomerTopcu (2015) suggests when voters perceive a high unity in 
the party. Yet, this effect drops significantly and even reverses as voters' perception of party unity decreases. Most importantly, this conditional effect of party unity on voters' perceptions is then perfectly translated into their voting behavior. Being ambiguous makes voters more likely to vote for the party; yet, this tendency is moderated when perceived party unity declines.

There are limitations of the present research. The empirical results we present in this study are based on German parties only, which may raise a question on the generalizability of our findings. However, Germany is certainly a hard test for our hypotheses because German parties are fairly cohesive in their behavior. We thus expect that voters in other countries should behave similarly or react even stronger to intraparty fights. Another issue we cannot address in this article is that respondents may interpret the survey scales employed to locate parties' policy positions and their unity differently (i.e. the DIF issue). ${ }^{17}$ Unfortunately, regular methods to tackle this issue explicitly assume that policy positions are not ambiguous (Aldrich and McKelvey, 1977: 112). Thus, further research is needed to establish whether the DIF issue limits the generalizability of our findings to other settings.

Our findings are of importance to our understanding of parties' electoral strategies, intraparty politics, and political representation. First, besides corroborating Somer-Topcu's (2015) findings using a different data set, we contribute to the literature that studies parties' strategic usage of ambiguous messages (e.g. Bräuninger and Giger, 2016; Tomz and Van Houwelling, 2009). We challenge the notion that voters are able to perceive the extent to which a party is ambiguous, which is often an assumption adopted in the theoretical literature (e.g. Argones and Neeman, 2000; Callander and Wilson, 2008; Shepsle, 1972). We argue and find empirical support for the idea that voters may be less aware of how precise party policy positions are, an assumption that is likely to change the conclusion drawn from many models that focus on ambiguous party positions.

Second, we begin to lay out the notion of how parties' policy positions and the corresponding ambiguity evolve. ${ }^{18}$ Most models of policy ambiguity assume that parties can set the level of policy ambiguity freely, just as they can freely select a policy position (e.g. Shepsle, 1972). We, by contrast, stress the role intraparty politics plays in party ambiguity. Our results suggest that both a party's policy position and its ambiguity are products of collective collaboration among all party members or party factions. While there are many circumstances in which parties seek the same goal in a unified manner, there are certainly internal fights that may distort the provision of a unified, strategically chosen policy position. As a consequence, future research should study how competition within parties, say between party factions (Ceron, 2012), affects party policy positions and ambiguity.
Third, our results potentially provide a partial answer to the debate on the electoral implications of embracing an ambiguous platform. Specifically, while both SomerTopcu (2015) and Tomz and Van Houweling (2009) suggest that being ambiguous is an electorally beneficial strategy, recent work by Aldrich et al. (2018) finds evidence that ambiguity actually leads to electoral penalties. In this article, we show that party unity plays an important role that conditions the electoral consequence of the broadappeal strategy. Parties are rewarded for doing so only when they are internally coherent, while they are punished for being ambiguous when they are internally divided.

Fourth, the results highlight why party unity is such a precious resource in party politics (Greene and Haber, 2015). Simply put: Well-conducted campaigns that rely on somewhat ambiguous policy statements (i.e. the broad-appeal strategy) can be easily undermined by intraparty conflicts. As a consequence, party leaders have strong incentives to form a broad coalition within the party to minimize the risk of party mavericks baffling their plans (Cross and Blais, 2012). Moreover, they face strong incentives to prohibit public debate within the party. Finally, party factions that compete with one another are likely to publicly announce their policy position hoping that other party factions will embrace that position for the sake of party coherence.

Fifth, the implications mentioned above challenge the links between citizens and parties in political representation. Most prominently, the Responsible Party Model of political representation is based on the assumption that parties take clear, distinct policy positions that voters use to make vote choices. While clear party stance educates citizens about how parties represent their interests (Mair, 2008), our findings suggest that parties are likely to blur their policy positions in order to gain votes. As a consequence, many voters are likely to misperceive which party reflects their preferences best, and hence, the connection between voters' preferences and government policy is likely to be weakened or even broken.

A final aspect of political representation that is challenged by our findings is deliberation within political parties. As Teorell (1999) argues, parties ought to be internally democratic - that is, to be equivocal - to allow citizens' needs to be put on the agenda. Our results, however, indicate that parties face clear incentives to appear internally united, that is, to not publicly fight about policies. In other words, our results suggest that parties face a trade-off between democratic representation on the one hand and electoral success on the other hand.

\section{Declaration of conflicting interests}

The author(s) declared no potential conflicts of interest with respect to the research, authorship, and/or publication of this article. 


\section{Funding}

The author(s) disclosed receipt of the following financial support for the research, authorship, and/or publication of this article: Both authors acknowledge funding by the Deutsche Forschungsgemeinschaft (DFG) via Collaborative Research Center (SFB) 884 "The Political Economy of Reforms" (projects C1 and C2) at the University of Mannheim.

\section{ORCID iD}

Roni Lehrer (D) https://orcid.org/0000-0002-9202-9278

\section{Supplemental material}

Supplemental material for this article is available online.

\section{Notes}

1. A couple of weeks later, the federal party board did institute the suspension procedure. Again, however, the coparty chairpersons took opposing sides. Furthermore, party expulsion can only be mandated by intraparty courts whose positions are virtually unknown. So uncertainty about which way party policy would develop remained high (Polke-Majewski, 2017).

2. All major German polling companies reported this effect. For an overview of polls, see http:/www.wahlrecht.de/umfragen/ index.htm.

3. It is measured by the perceptual agreement score, which is used in Somer-Topcu (2015) as a proxy of the extent to which a party is ambiguous.

4. Besides substantial fights between party factions (Ceron, 2012), there are ample other ways in which voters can update their perceptions of party division. These include battles of words at party conferences (Greene and Haber, 2015), campaigns for party leadership selection (Kenig, 2009), speeches in parliament (Porksch and Slapin, 2015), experience in government (Greene and Haber, 2015), internal party rules (Lehrer, 2012; Schumacher et al., 2013), and many other factors. Future research will determine to what extent voters update their beliefs about intraparty conflict and party ambiguity from these sources (Adams et al., 2011, 2014).

5. Admittedly, parties in a coalition government have an incentive to reveal their true positions through conflicts to voters, while factions within a political party need not share the same motivation. Yet, they may use public channels (e.g. the media) to signal their policy positions to their faction supporters.

6. The parties included in the sample are CDU/CSU, SPD, Bündnis 90/Die Grünen, FDP, and Die Linke.

7. In both years, respondents were asked for party placements and self-placements in September, whereas party cohesiveness was measured in November. Even though respondents in November were asked to rate party cohesiveness thinking of the last 4 weeks, more recent GIP data indicates that respondents do not give different answers when no time span is mentioned.
8. The lack of a "correct" party measurement is certainly a limiting factor of our research design. We note, however, that respondents' mean belief about the party position should be a reliable proxy unless misperceptions are positively correlated (see Lehrer et al., Forthcoming). While it is certainly beyond the scope of this article to investigate this, we call for future research to scrutinize the potential differences between objective and perceived party positions as well as party ambiguity.

9. Theoretically, the perceptual agreement score ranges from -1 to 1 . We rescaled it to the $[0,1]$ interval. In our data set, it ranges between 0.09 and 0.27 .

10. Treating ambiguity as a continuous variable in our model yields very similar findings. The estimated results are reported in the Online Appendix.

11. The question reads: "Members of the same party sometimes express opposing views. When you recall the last four weeks, do you perceive the following party as fragmented or as cohesive."

12. We consider Die Linke as single issue party, and all other parties as multiple issue parties.

13. In the period of our surveys cover, CDU/CSU and SPD were the incumbent parties.

14. In the Online Appendix Table A3, we further show that adding respondent-specific fixed effects does not alter the conclusion drawn here.

15. Using the GIP survey, we successfully replicate Somer-Topcu's (2015) model and reproduce very similar findings. Being able to recover Somer-Topcu's findings using the GIP data is no doubt an important step. It helps us rule out the possibility that the differences we reveal after taking into account party unity might be artifacts of the data. The corresponding results are presented in the Online Appendix A.

16. The data structure in the second stage model is identical to the structure in the first stage model.

17. We thank an anonymous reviewer for pointing this out to us.

18. We thank one of the anonymous reviewers for pointing this out to us.

\section{References}

Adams J, Ezrow L and Somer-Topcu Z (2014) Do voters respond to party manifestos or to a wider information environment? An analysis of mass-elite linkages on European integration. American Journal of Political Science 58(4): 967-978.

Adams J, Ezrow L and Somer-Topcu Z (2011) Is anybody listening? Evidence that voters do not respond to European parties' policy statements during elections. American Journal of Political Science 55(2): 370-382.

Aldrich JH and McKelvey RD (1977) A method of scaling with applications to the 1968 and 1972 presidential elections. American Political Science Review 71(1): 111-130.

Aldrich JH, Schober GS, Ley S, et al. (2018) Incognizance and perceptual deviation: Individual and institutional sources of variation in citizens' perceptions of party placements on the left-right scale. Political Behavior 40(2): 415-433. 
Alesina A and Cukierman UA (1990) The politics of ambiguity. Quarterly Journal of Political Science 105(4): 829-850.

American Political Science Association, Committee on Political Parties (1950) Toward a More Responsible Two-Party System. New York: Rinehart.

Argones E and Neeman UZ (2000) Strategic ambituity in electoral competition. Journal of Theoretical Politics 112(2): 183-205.

Argones E and Postlewaite A (2002) Ambiguity in election games. Review of Economic Design 7(3): 233-255.

Bartels LM (1986) Issue voting under uncertainty: An empirical test. American Journal of Political Science 30(4): 709-728.

Bergholt D and Lujala UP (2012) Climate-related natural disasters, economic growth, and armed civil conflict. Journal of Peace Research 49(1): 147-162.

Blom AG, Gathmann C and Krieger UU (2015) Setting up an online panel representative of the general population: The German internet panel. Field methods 27(4): 391-408.

Blom AG, Bossert D and Funke F, et al; SFB 884 "Political Economy of Reforms" Universität Mannheim (2016a) German Internet Panel, Welle 1 - Core Study (September 2012). Köln: GESIS Datenarchiv. ZA5866 Datenfile Version 2.0.0. DOI: $10.4232 / 1.12607$

Blom AG, Bossert D and Funke F, et al; SFB 884 "Political Economy of Reforms" Universität Mannheim (2016b) German Internet Panel, Welle 2 (November 2012). Köln: GESIS Datenarchiv. ZA5867 Datenfile Version 2.0.0. DOI:10.4232/ 1.12608

Blom AG, Bossert D and Gebhard F, et al; SFB 884 "Political Economy of Reforms" Universität Mannheim (2016c) German Internet Panel, Welle 7 - Core Study (September 2013). Köln: GESIS Datenarchiv. ZA5872 Datenfile Version 2.0.0. DOI: $10.4232 / 1.12613$

Blom AG, Bossert D and Funke F; SFB 884 "Political Economy of Reforms" Universität Mannheim (2016d) German Internet Panel, Welle 8 (November 2013). Köln: GESIS Datenarchiv. ZA5873 Datenfile Version 2.0.0. DOI: 10.4232/1.12614

Börnsen W (2017) Die 100-prozent-blackbox. Available at: www. tagesschau.de/inland/schulz-wahl-spd-105.html (accessed 20 March 2017).

Bräuninger T and Giger UM (2018) Strategic ambiguity of party positions in multi-party competition. Political Science Research and Methods 6(3): 527-548.

Budge I (1994) A new spatial theory of party competition: uncertainty, ideology and policy equilibria viewed comparatively and temporally. British Journal of Political Science 24(4): 443-467.

Callander S and Wilson UCH (2008) Context-dependent voting and political ambiguity. Journal of Public Economics 92(3): $565-581$.

Caspari L (2017) König der Umfragen. Available at: http://www. zeit.de/politik/deutschland/2017-02/martin-schulz-spd-cduumfragen (accessed15 March 2017).

Ceron A (2012) Bounded oligarchy: how and when factions constrain leaders in party position-taking. Electoral Studies 31(4): 689-701.
Cross WP and Blais UA (2012) Politics at the Centre: The Selection and Removal of Party Leaders in the Anglo Parliamentary Democracies. Oxford: Oxford University Press.

Dahlberg S (2009) Political parties and perceptual agreement: the influence of party related factors on voters' perceptions in proportional electoral systems. Electoral Studies 28(2): $270-278$.

Downs A (1957) An Economic Theory of Democracy. New York: Harper.

Enelow J and Hinich MJ (1981) A new approach to voter uncertainty in the Downsian spatial model. American Journal of Political Science 25: 483-493.

Fortunato D and Stevenson URT (2013) Perceptions of partisan ideologies: the effect of coalition participation. American Journal of Political Science 57(2): 459-477.

Glazer A (1990) The strategy of candidate ambiguity. The American Political Science Review 84(1): 237-241.

Gill J (2005) An entropy measure of uncertainty in vote choice. Electoral Studies 24(3): 371-392.

Greene ZD and Haber UM (2015) The consequences of appearing divided: an analysis of party evaluations and vote choice. Electoral Studies 37: 15-27.

Hersh ED and Schaffner UBF (2013) Targeted campaign appeals and the value of ambiguity. The Journal of Politics 75(2): 520-534.

Hickmann Christoph. (2017). “Alle lieben Schulz - noch”. Available at: https://www.sueddeutsche.de/politik/spd-alle-liebenschulz-noch-1.3360907. (accessed 12 November 2018).

Jensen T (2009) Projection effects and strategic ambiguity in electoral competition. Public Choice 141: 213-232.

Kamann Matthias (2017). "Warum AfD-Chefin petry gegen höcke schlechte Karten hat”. Available at: https:/www.welt. de/politik/deutschland/article161698986/Warum-AfD-Che fin-Petry-gegen-Hoecke-schlechte-Karten-hat.html (accessed 12 November 2018).

Kedar O (2005) When moderate voters prefer extreme parties: policy balancing in parliamentary elections. American Political Science Review 99(2): 185-199.

Kenig Ofer (2009) Democratization of party leadership selection: Do wider selectorates produce more competitive contests? Electoral Studies 28(2): 240-247.

King G, Tomz M and Wittenberg UJ (2000) Making the most of statistical analyses: improving interpretation and presentation. American Journal of Political Science 44(2): $347-361$.

Laver M (2005) Policy and the dynamics of political competition. American Political Science Review 99(2): 263-281.

Lehrer R (2012) Intra-party democracy and party responsiveness. West European Politics 35(6): 1295-1319.

Lehrer R, Juhl S and Gschwend T (Forthcoming) The wisdom of crowds design for sensitive survey questions. Electoral Studies. DOI: 10.1016/j.electstud.2018.09.012

Mair P (2008) The challenge to party government. West European Politics 31(1-2): 211-234. 
Martin LW and Vanberg UG (2008) Coalition government and political communication. Political Research Quarterly 61: 502-516.

Martin LW and Vanberg UG (2011) Parliaments and Coalitions: The Role of Legislative Institutions in Multiparty Governance. Oxford: Oxford University Press.

McFadden D (1973) Conditional logit analysis of qualitative choice behavior. In: herausgegeben von PZ (ed.) Frontiers in Econometrics. New York: Wiley.

Meirowitz A (2005) Informational party primaries and strategic ambiguity. Journal of Theoretical Politics 17(1): 107136.

Merrill S, Grofman B and Adams UJ (2001) Assimilation and contrast effects in voter projections of party locations: Evidence from Norway, France, and the USA. European Journal of Political Research 40(2): 199-221.

Polke-Majewski (2017) Alternative für Deutschland. Nur ein Machtkampf [In German]. Available at: http://www.zeit.de/ politik/deutschland/2017-02/alternative-fuer-deutschlandbjoern-hoecke-ausschluss-partei-machtkampf (accessed 28 February 2017).

Proksch S-O and Slapin JB (2015) The Politics of Parliamentary Debate: Parties, Rebels and Representation. Cambridge: Cambridge University Press.

Rovny J (2012) Who emphasizes and who blurs? Party strategies in multidimensional competition. European Union Politics 13(2): 269-292.

Sagarzazu I and Klüver UH (2017) Coalition governments and party competition: political communication strategies of coalition parties. Political Science Research and Methods 5(2): 333-349.

Gijs S, de Vries Catherine E and Vis Barbara (2013). Why do parties change position? Party organization and environmental incentives. The Journal of Politics 75(2): 464-477.
Shepsle KA (1972) The strategy of ambiguity: uncertainty and electoral competition. The American Political Science Review 66(2): 555-568.

Somer-Topcu Z (2015) Everything to everyone: the electoral consequences of the broad-appeal strategy in Europe. American Journal of Political Science 59(4): 841-854.

Somer-Topcu Z (2009) Timely decisions: the effects of past national elections on party policy change. The Journal of Politics 71(1): 238-248.

Spoon JJ and Klüver UH (2017) Does anybody notice? How policy positions of coalition parties are perceived by voters. European Journal of Political Research 56(1): 115-132.

Teorell J (1999) A deliberative defence of intra-party democracy. Party politics 5(3): 363-382.

Tomz M and Van Houwelling UR (2009) The electoral implications of candidate ambiguity. American Political Science Review 103(1): 83-98.

Van der Eijk C (2001) Measuring agreement in ordered rating scales. Quality and Quantity 35(3): 325-341.

Wittman DA (1973) Parties as utility maximizers. American Political Science Review 67(2): 490-498.

\section{Author biographies}

Roni Lehrer is a postdoctoral researcher at the Collaborative Research Center (SFB884) at the University of Mannheim. His research focuses on intraparty politics, party policy diffusion, and political representation in advanced democracies.

Nick Lin is an assistant research fellow at the Institute of Political Science at Academia Sinica in Taiwan and a research associate at the Collaborative Research Center (SFB884) at the University of Mannheim. His research interests encompass several themes of comparative politics, including comparative political institutions, comparative political behavior, parties and elections, and legislative politics. 